\title{
Rock Mass Classification for Columnar Jointed Basalt: A Case Study of Baihetan Hydropower Station
}

\author{
Shiyue Zhang, ${ }^{1,2,3}$ Mingjie He, ${ }^{4}$ Jinjian Gu, ${ }^{4}$ Zhihao Cui, ${ }^{2,3}$ Jian Wang, ${ }^{2,3}$ Lin Zhong, ${ }^{5}$ \\ Qingxiang Meng, ${ }^{2,3}$ and Huanling Wang $\mathbb{D}^{6}$ \\ ${ }^{1}$ Shanghai Research Institute of Materials, Shanghai 200437, China \\ ${ }^{2}$ Key Laboratory of Ministry of Education for Geomechanics and Embankment Engineering, Hohai University, \\ Nanjing 210098, China \\ ${ }^{3}$ Research Institute of Geotechnical Engineering, Hohai University, Nanjing 210098, China \\ ${ }^{4}$ Huadong Engineering Corporation Limited, Hangzhou 311122, China \\ ${ }^{5}$ Nanjing Yangtze River Management Office, Nanjing 210011, China \\ ${ }^{6}$ Key Laboratory of Coastal Disaster and Defense, Ministry of Education, Hohai University, Nanjing 210098, China \\ Correspondence should be addressed to Huanling Wang; wanghuanling@hhu.edu.cn
}

Received 19 October 2020; Revised 18 November 2020; Accepted 25 November 2020; Published 29 December 2020

Academic Editor: Chun Zhu

Copyright (C) 2020 Shiyue Zhang et al. This is an open access article distributed under the Creative Commons Attribution License, which permits unrestricted use, distribution, and reproduction in any medium, provided the original work is properly cited.

\begin{abstract}
Rock mass classification is important in preliminary design of geotechnical engineering projects. Using the columnar jointed basalt at the foundation of Baihetan Hydropower Station as an example, this paper presents a classification scheme of the columnar jointed rock. Unlike many common rock masses, an obvious characteristic of columnar jointed rock is that it is discontinuous in geometry while continuous in mechanics. Due to the inapplicability of existing rock mass classification systems, a classification scheme, combined with rock mass integrity, weak plane tightness, and permeability, is proposed. The new classification system has five grades with quantitative factors, which takes into account the features of columnar joints. As an easy-to-use scheme and case study, it would be helpful as a reference in the rock mass classification of similar problems.
\end{abstract}

\section{Introduction}

Columnar jointing is a typical fracture pattern (shown in Figure 1), best known from such locations as the Giant's Causeway or Fingal's Cave, in which cracks self-organize into a nearly hexagonal arrangement, forming an ordered colonnade $[1,2]$. As a miraculous natural phenomenon, there is a long research history since the Giant's Causeway was first reported in the 17th century [3]. Nowadays, the formation of columnar joints is reasonably understood as a result of cracks propagating into cooling lava flows [4-7]. As a kind of adverse geologic condition, a reasonable and suitable rock mass classification is extremely important for engineering projects.

Developing the hydropower energy to the west is a trend in China [8-10]. With the booming development of the water conservancy and hydropower projects, more and more com- plicated engineering geological conditions, such as columnar jointed rock, are encountered. At the foundation of Baihetan Hydropower Station, columnar jointed rock mass is widely distributed. A large number of laboratory and in situ tests give a clear illustration of the characteristics of columnar joints and similar jointed rock mass [11-16]. Unlike other traditional types of rock mass, the geologic structure of columnar jointed basalt is very complex $[17,18]$. Due to the cuts of joints, the value of rock quality designation (RQD) is quite low, and it will be identified as fragmentized rock mass using existing rock classification methods [19, 20]. However, the seismic velocities $V_{p}$ are high and the rock strengths are high in certain stress states. It has typical characteristics of discontinuity in geometry and continuity in mechanical properties. The rock quality will be substantially underestimated, and traditional rock classification system is not suitable for such type of rock mass. 


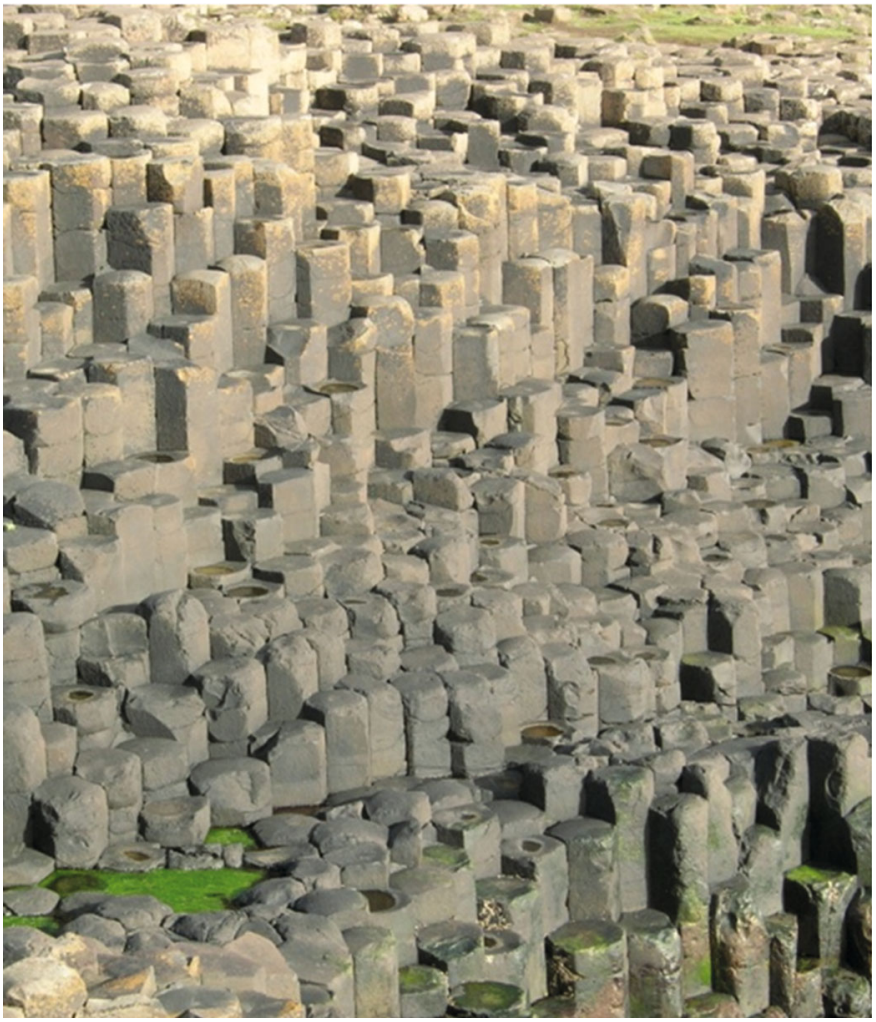

(a)

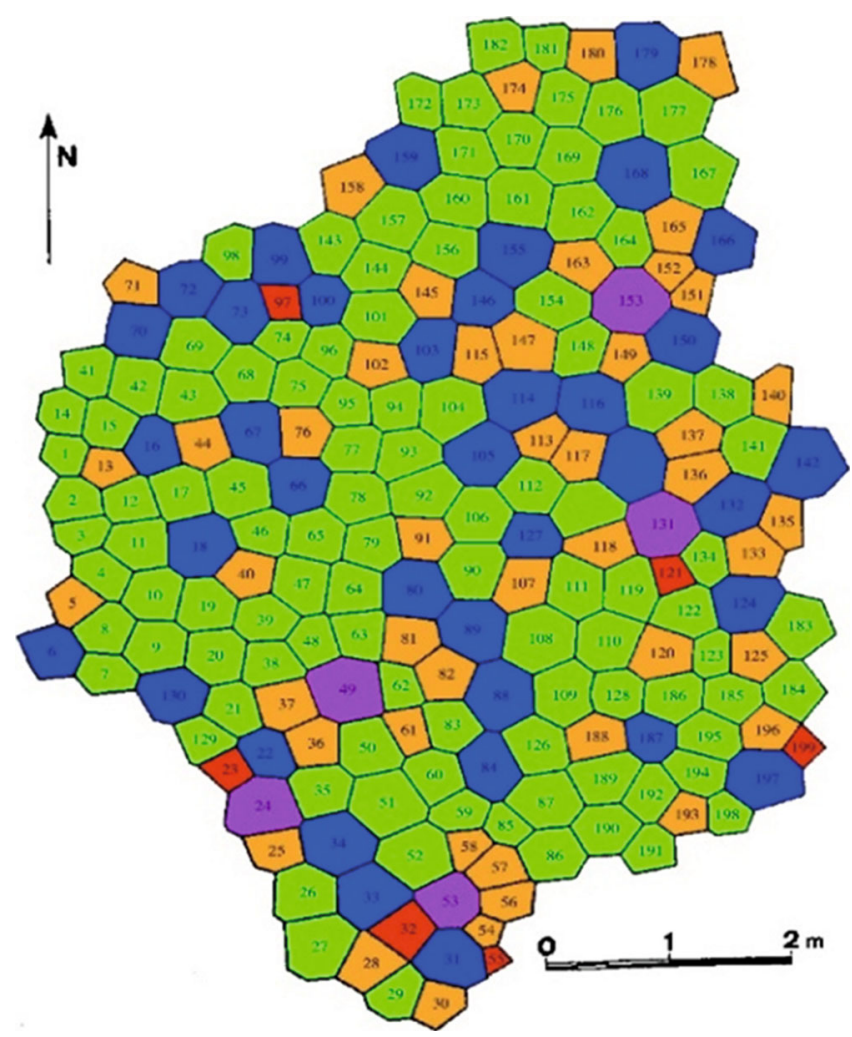

(b)

FIgURE 1: Typical columnar jointed rock masses: (a) Giant's Causeway, Antrim in Northern Ireland and (b) colorized map of about 200 columns [1].

Considering the exact measurement of mechanical property is very difficult [21-27], rock mass classification methods are commonly used at the preliminary design stage of a construction project. Considering the inapplicability of existing rock classification systems, a rock classification system, integrating a set of key factors controlling the rock quality such as weathering, degree of stress release, degree of integrity of rock mass, and permeability, is proposed. A case study on columnar jointed basalt is conducted; the results may be extended to other similar cases or used as reference for other engineering projects.

\section{Existing Rock Mass Classification Systems}

A proper rock mass classification can give engineers a quick and reliable estimation of the rock mass without complicated calculations of various parameters. It forms the basis for design and estimation of the required amount and the type of rock support in groundwater control measures. A wellknown early attempt is Terzaghi's classification system for support of tunnels. Based on the most important inherent and structural parameters, several other classification systems, such as RMR, GSI, and Q, have been proposed and widely used in engineering. A detailed list of rock mass classification systems is presented in Table 1.
From these rock classification systems, the factors involved in the existing empirical classification systems are related mainly to the general information of rock mass, geometric characteristics of discontinuities, and construction method. Over the past several decades, the existing rock mass classifications have been applied successfully in tunneling, underground mining, and slopes. However, it is noted that considerable caution must be exercised in applying a rock mass classification to other rock engineering problems, although the classification scheme is appropriate for its original applications.

Columnar jointed basalt rock, as a kind of special rock mass, is not suitable to be classified with these factors, and sometimes, the results are evidently inconsistent under different classification schemes. Furthermore, many effective factors in rock mass descriptions, such as underground water and seismic velocity, are absent in existing classification schemes. The objective of this paper is to propose a classification scheme for columnar jointed basalt based on a comprehensive understanding of its properties.

\section{Geological Conditions}

Baihetan Hydropower Station is located on the downstream reaches of the Jinsha River, at the border of Ningnan County of Sichuan Province and Qiaojia County of Yunnan Province 
TABLE 1: Existing rock mass classification systems.

\begin{tabular}{|c|c|c|c|c|}
\hline Name & Abbrev. & Authors & Application & Comments \\
\hline- & - & Ritter [28] & Tunnels & $\begin{array}{l}\text { The first attempt for the formalization of } \\
\text { an empirical approach to tunnel design. }\end{array}$ \\
\hline Rock load & - & Terzaghi [29] & Tunnels & $\begin{array}{l}\text { The earliest reference to the use of rock mass } \\
\text { classification for the design of tunnel support. }\end{array}$ \\
\hline Stand-up time & - & Lauffer [30] & Tunnels & $\begin{array}{l}\text { Related to the stand-up time of an unsupported } \\
\text { tunnel excavation. }\end{array}$ \\
\hline $\begin{array}{l}\text { Rock quality } \\
\text { designation }\end{array}$ & RQD & Deere $[31]$ & General & Component factor of many classification systems. \\
\hline Rock structure rating & RSR & Wickham et al. [32] & Tunnels & First rating system for rock masses. \\
\hline $\begin{array}{l}\text { Rock tunneling } \\
\text { quality index }\end{array}$ & Q & Barton et al. [33] & Tunnels & The most commonly used classification systems for tunnels. \\
\hline Rock mass rating & RMR & Bieniawski [34] & $\begin{array}{l}\text { Tunnels and } \\
\text { cuttings }\end{array}$ & Widely used for both tunnels and slopes. \\
\hline Rock mass index & $\mathrm{RMi}$ & Palmstrom [35] & Tunnels & An approximate value for the compressive strength. \\
\hline $\begin{array}{l}\text { New Austrian } \\
\text { tunneling method }\end{array}$ & NATM & Rabcewicz [36] & Tunnels & Used in the determination of support measures. \\
\hline $\begin{array}{l}\text { Mining rock mass } \\
\text { rating }\end{array}$ & MRMR & Laubscher [37] & Mines & Based on RMR (1973). \\
\hline Rock mass strength & RMS & Selby [38] & Cuttings & Based on natural slope database. \\
\hline Slope mass rating & SMR & Romana [39] & Cuttings & $\begin{array}{l}\text { Based on RMR (1979). The most commonly used } \\
\text { classification system for slopes. }\end{array}$ \\
\hline $\begin{array}{l}\text { Slope rock mass } \\
\text { rating }\end{array}$ & SRMR & Robertson $[40]$ & Cuttings & $\begin{array}{l}\text { Based on RMR. The classification is provided for of weak } \\
\text { altered rock mass materials from drill hole cores. }\end{array}$ \\
\hline $\begin{array}{l}\text { Chinese slope mass } \\
\text { rating }\end{array}$ & CSMR & Chen $[41]$ & Cuttings & $\begin{array}{l}\text { Adjustment factors have been applied to the SMR system for } \\
\text { the discontinuity condition and slope height. }\end{array}$ \\
\hline $\begin{array}{l}\text { Geological strength } \\
\text { index }\end{array}$ & GSI & Hoek et al. [42] & General & $\begin{array}{l}\text { Based on RMR (1976). For nonstructurally controlled } \\
\text { failures. }\end{array}$ \\
\hline $\begin{array}{l}\text { Modified rock mass } \\
\text { rating }\end{array}$ & M-RMR & Unal $[43]$ & Mines & $\begin{array}{l}\text { For weak, stratified, anisotropic, and } \\
\text { clay-bearing rock masses. }\end{array}$ \\
\hline Basic quality & $\mathrm{BD}$ & $\begin{array}{l}\text { Ministry of Water } \\
\text { Resources, PRC [44] }\end{array}$ & General & Engineering quality classification of rock mass in China. \\
\hline $\begin{array}{l}\text { Rock slope } \\
\text { deterioration } \\
\text { assessment }\end{array}$ & RDA & $\begin{array}{l}\text { Nicholson and } \\
\text { Hencher [45] }\end{array}$ & Cuttings & $\begin{array}{l}\text { For shallow, weathering-related breakdown of } \\
\text { excavated rock slopes. }\end{array}$ \\
\hline $\begin{array}{l}\text { Slope stability } \\
\text { probability } \\
\text { classification }\end{array}$ & SSPC & Hack et al. [46] & Cuttings & $\begin{array}{l}\text { Probabilistic assessment of independently different } \\
\text { failure mechanics. }\end{array}$ \\
\hline $\begin{array}{l}\text { Volcanic rock face } \\
\text { safety rating }\end{array}$ & VRFSR & $\begin{array}{l}\text { Singh and Connolly } \\
\text { [47] }\end{array}$ & $\begin{array}{c}\text { Cuttings } \\
\text { (temporary } \\
\text { excavations) }\end{array}$ & $\begin{array}{l}\text { For volcanic rock slopes to determine the excavation safety } \\
\text { on construction sites. }\end{array}$ \\
\hline $\begin{array}{l}\text { Falling rock hazard } \\
\text { index }\end{array}$ & FRHI & Singh [48] & $\begin{array}{c}\text { Cuttings } \\
\text { (temporary } \\
\text { excavations) }\end{array}$ & $\begin{array}{l}\begin{array}{l}\text { Developed for stable excavations to determine the degree of } \\
\text { danger to workers. }\end{array}\end{array}$ \\
\hline $\begin{array}{l}\text { Basic geotechnical } \\
\text { description }\end{array}$ & BGD & ISRM [49] & General & Established in 1981 by ISRM. \\
\hline $\begin{array}{l}\text { Size strength } \\
\text { classification }\end{array}$ & SSC & Franklin $[50]$ & Tunneling & $\begin{array}{c}\text { Based on the strength of intact rock and the spacing of } \\
\text { discontinuities. }\end{array}$ \\
\hline $\begin{array}{l}\text { Simplified rock mass } \\
\text { rating }\end{array}$ & SRMR & $\begin{array}{c}\text { Brook and } \\
\text { Dharmaratne }[51]\end{array}$ & General & $\begin{array}{l}\text { Three major components: the intact rock strength, joint } \\
\text { spacing, and joint type. }\end{array}$ \\
\hline
\end{tabular}

(Figure 2). It is one of the cascade hydropower stations on the Jinsha River, with the Wudongde Hydropower Station on the upstream side and Xiluodu Hydropower Station $195 \mathrm{~km}$ away on the downstream side. As the second level of the cascade hydropower stations on Jinsha River, Baihetan Hydropower Station is a concrete double-curvature arch dam with 


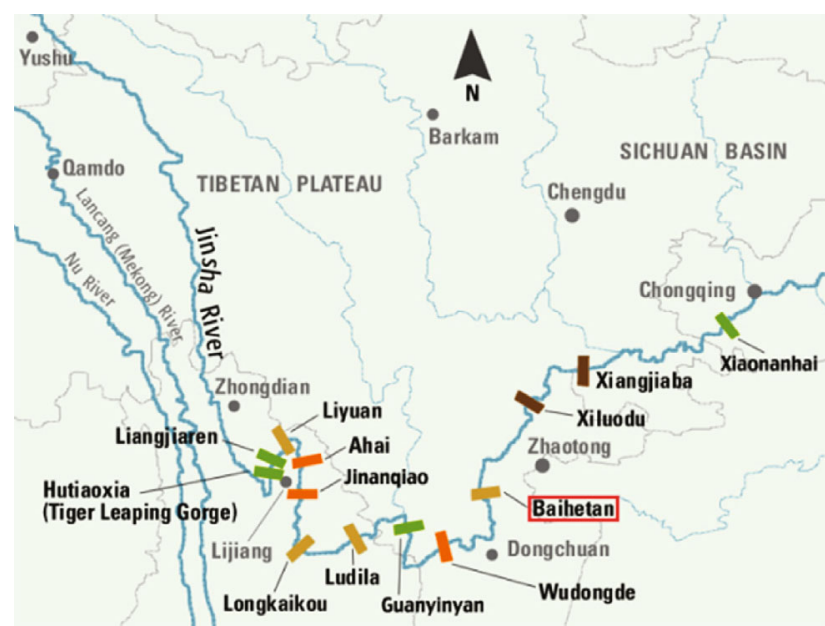

(a)

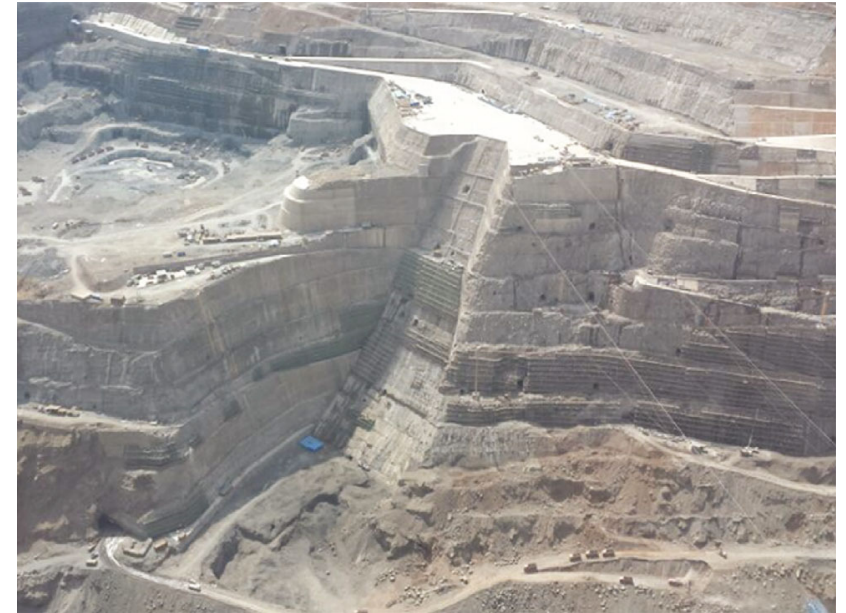

(b)

Figure 2: Baihetan Hydropower Station: (a) location of the hydropower station and (b) construction site.

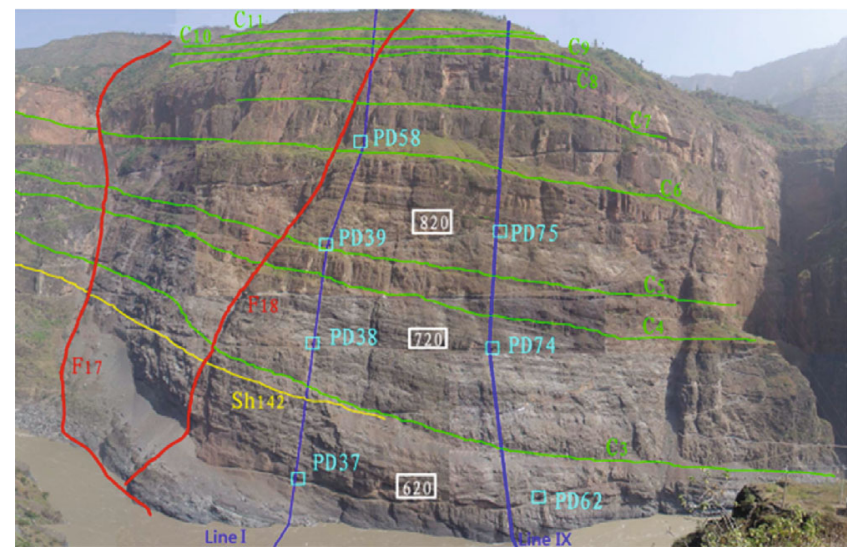

(a)

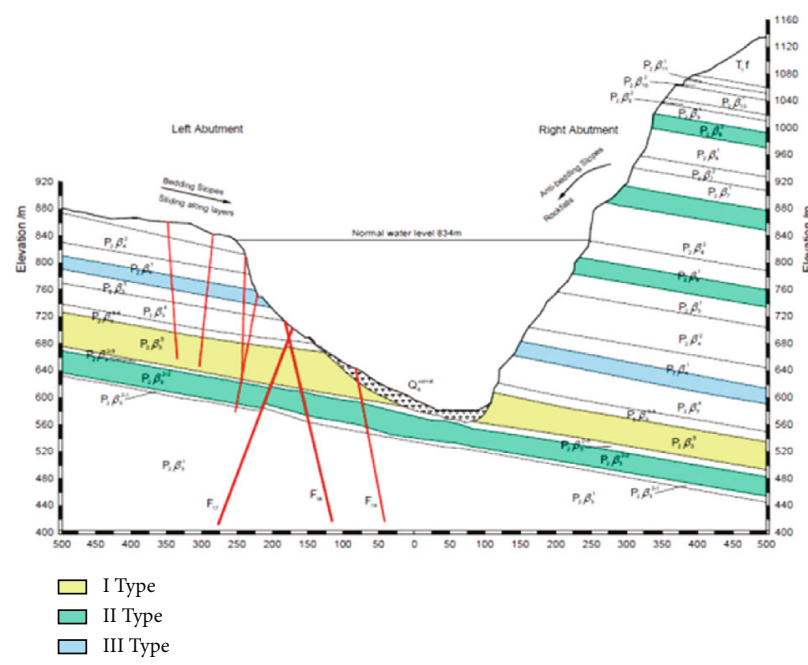

(b)

Figure 3: Profile distribution of columnar basalt at Baihetan dam site: (a) left bank of dam site and (b) profile information of Line I.

a height of $289 \mathrm{~m}$ and installed plant capacity of 14,004 MW. The dam site is about $260 \mathrm{~km}$ from Kunming and about $400 \mathrm{~km}$ from Chongqing, Chengdu, or Guiyang, respectively. The straight distance between the dam site and Shanghai of the East China Region is around $1850 \mathrm{~km}$. The site is located to the east of Zemuhe and Sikai-Jiaojihe fracture zones and to the north of Xiaojiang fracture zone. Although active facture zones exist in this region and the regional seismic activities are intense, no intense earthquake has been recorded in a $40 \mathrm{~km}$ range around the dam site.

3.1. Geomorphology and Topography. The river valley at the dam site is asymmetrical and is of a $\mathrm{V}$ shape, with massive mountains on both sides. On the left bank, the landform above El. $850 \mathrm{~m}$ is wide and flat at No. 1 Exploration Line, while the landform below alternates with gentle and steep slopes or cliffs. On the right bank, the landform above El.
$1170 \mathrm{~m}$ consists of gentle slopes, whereas cliffs and steep slopes cover the land below El. $1170 \mathrm{~m}$. The outcrops at the dam site are mainly Emei basalt formed in the late Permian Period, with underlying Maokou limestone formed in the early Permian Period. The river alluvial, about 5 to $25 \mathrm{~m}$ in thickness, is composed of Holocene boulders with sand. The Q4 unconsolidated deposits distribute mainly on riverbed, terraces, and sloping mesas. An illustration of the distribution of columnar joints is presented in Figure 3.

It can be seen that the middle dam site is mainly composed of $P_{2} \beta_{2} \sim P_{2} \beta_{6}$ basalts, basically including microliticaphanitic basalt, amygdaloidal basalt, and varied basaltic brecciated lava (Figure 4). The rocks are hard but developed with some columnar joints, especially in the middle portion of $P_{2} \beta_{3}$ stratum where the diameters of columns range from $5 \mathrm{~cm}$ to $10 \mathrm{~cm}$; the columnar joints in other strata range from $20 \mathrm{~cm}$ to $30 \mathrm{~cm}$. Weak basalt or brecciated tuff interlayers in 


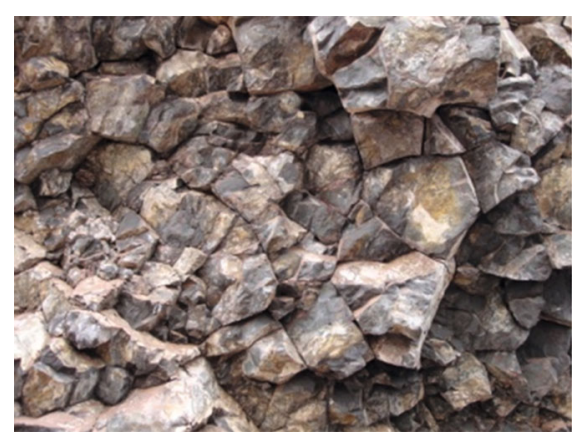

(a)

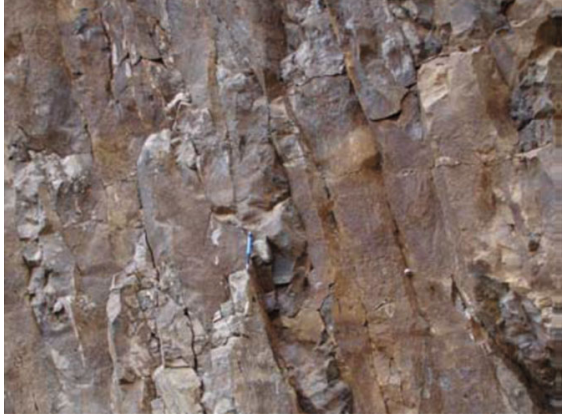

(b)

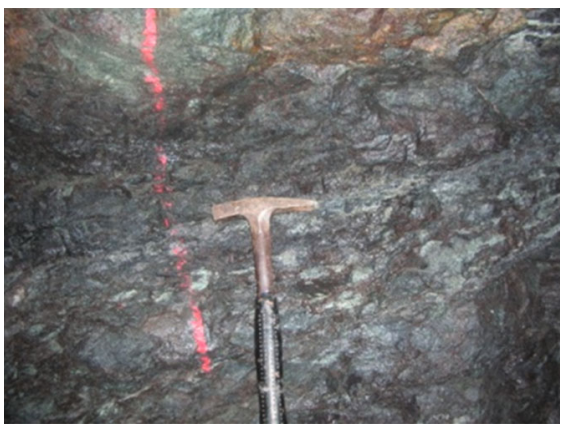

(c)

FIgURE 4: Typical columnar jointed rock at Baihetan dam site: (a) strongly weathered, (b) slightly weathered, and (c) fresh.

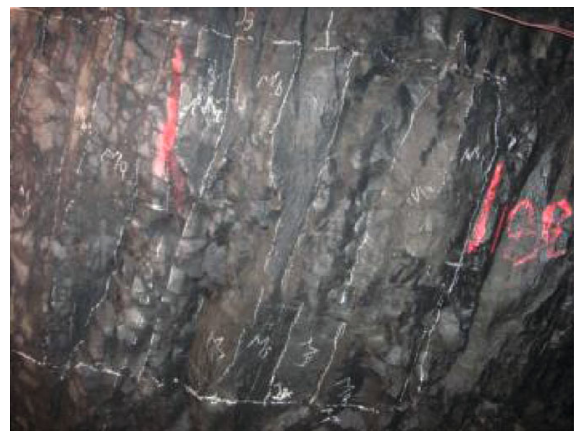

(a)

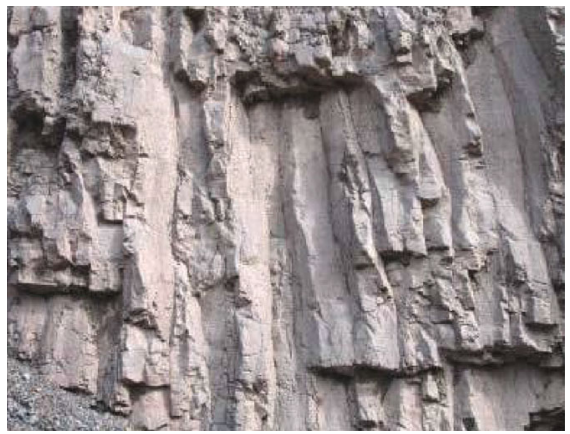

(b)

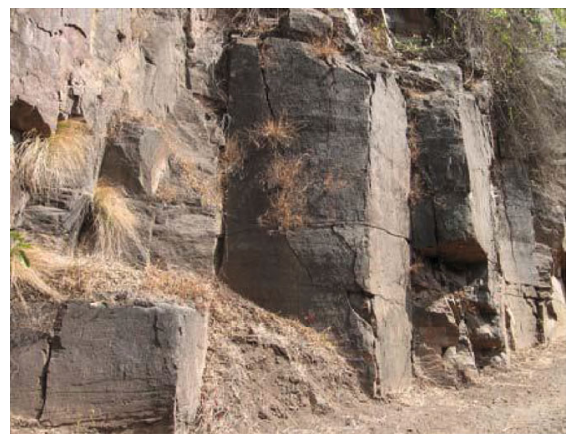

(c)

Figure 5: Typical columnar jointed rock mass: (a) Type I, (b) Type II, and (c) Type III.

different thicknesses are distributed at top of basalt strata, with thickness of $0.3 \mathrm{~m}$ to $1.7 \mathrm{~m}$ for lower strata and $0.3 \mathrm{~m}$ to $9 \mathrm{~m}$ for upper strata $\left(P_{2} \beta_{9}\right.$ to $\left.P_{2} \beta_{11}\right)$ [52].
The faults in the dam site are small in scale, and there is no regional fault. Most faults are of strike-slip type, and a few of them are thrust faults. Geological structures are 


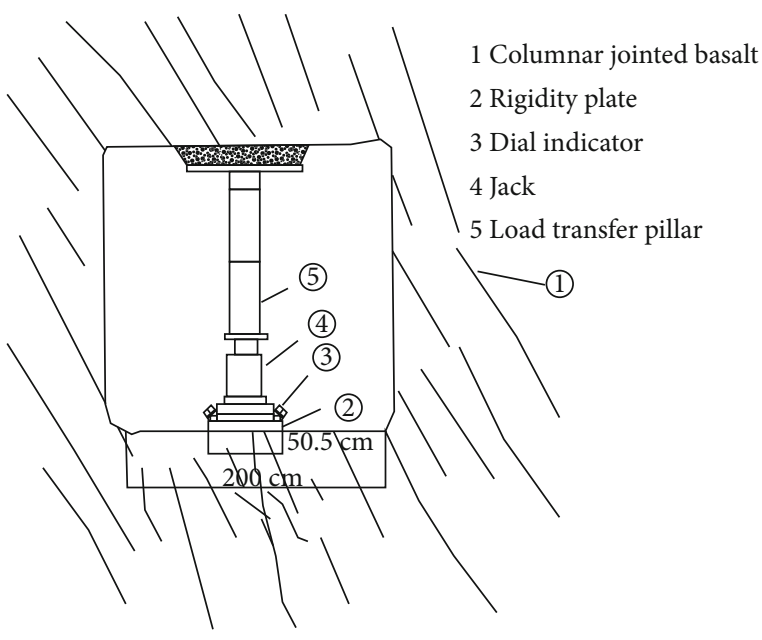

(a)

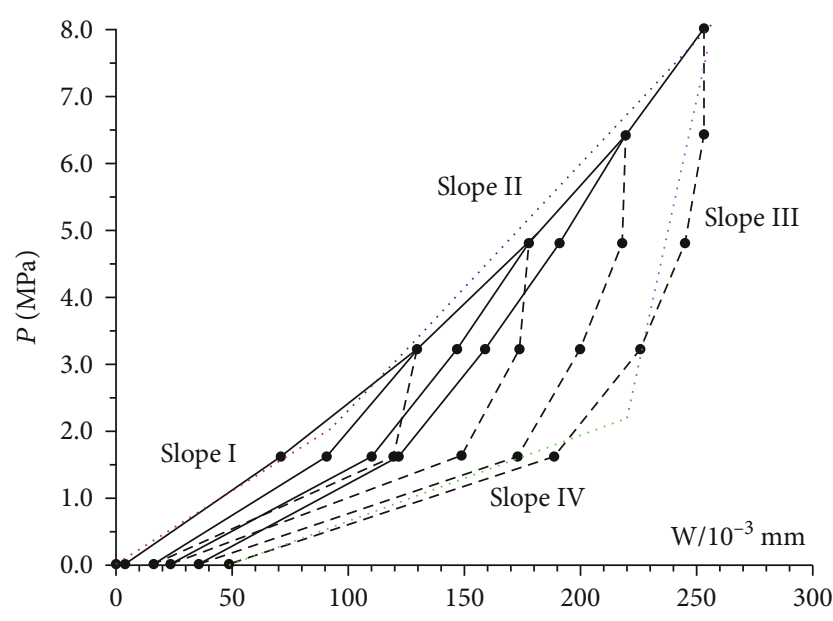

(b)

FIGURE 6: Deformation of columnar jointed basalt: (a) illustration of equipment system and (b) typical loading-unloading curve of columnar jointed rock.

composed of mainly faults with thickness less than $1.0 \mathrm{~m}$, fracture zones, and joints, mostly striking NW with a few striking NE, and most of them are dipping at high angles. Outcrop rocks in both banks are weakly weathered, and the underlying rocks are slightly weathered and relatively intact. The load release effect influences rocks on both banks to various depths and deeper in the left bank. The underground water level and relatively impermeable layer are comparatively deep.

3.2. Hydrometeorology. The main source of runoff in the Jinsha River is from precipitation and replenished by the melt snow from the upstream area. The annual runoff is concentrated mainly in June to November, accounting to around 80 percent of the total. An analysis on runoff data of 61 years from June 1939 to December 2000 indicates that the average annual discharge at the Baihetan dam site is $4110 \mathrm{~m}^{3} / \mathrm{s}$. Floods in the Jinsha River originate mainly from rainstorms. The maximum peak floods of the Jinsha River occur mainly in July to September (over 95 percent of the total numbers), and the remaining 5 percent of floods occur in the last ten days of June or the first twenty days of October.

The annual average temperature at the Baihetan dam site is $21.7^{\circ} \mathrm{C}$, with the highest and lowest recorded temperatures being $42.2^{\circ} \mathrm{C}$ and $2.1^{\circ} \mathrm{C}$, respectively. The annual average water temperature is $17.4^{\circ} \mathrm{C}$. The mean annual rainfall at the dam site is $715.9 \mathrm{~mm}$, and there are about 100 precipitation days in a year. The annual average wind velocity is $2.1 \mathrm{~m} / \mathrm{s}$ at the dam site, with the maximum being $13 \mathrm{~m} / \mathrm{s}$ in south direction.

\section{Columnar Jointed Basalt in Baihetan}

The development of joint fissures in columnar jointed rock mass is heterogeneous. The columnar jointed basalt can be
TABLE 2: UCS classification for columnar jointed rock mass.

\begin{tabular}{lccccc}
\hline Level & Good & Relative good & Moderate good & Relatively bad & Bad \\
\hline UCS & $>200$ & $50 \sim 200$ & $10 \sim 50$ & $3 \sim 10$ & $<3$
\end{tabular}

classified into three categories based on the columnar size and length.

Type I rock masses have columnar mosaic structures with high fractural densities, and the joint planes are undulating and rough (Figure 5). The columns have a length of 2 to $3 \mathrm{~m}$ and a diameter of 13 to $25 \mathrm{~cm}$, and microfractures develop to cut the columns into small blocks with 5 different diameters. Type I columnar basalt distributes in mainly two sublayers: $P_{2} \beta_{2}$ and $P_{2} \beta_{3}$. Type II columnar jointed masses, distributed in mainly $P_{2} \beta_{3}{ }^{2}$, $P_{2} \beta_{6}{ }^{1}, P_{2} \beta_{7}{ }^{1}$, and $P_{2} \beta_{8}{ }^{2}$, have a height of 0.5 to $20 \mathrm{~m}$ and a diameter of 25 to $50 \mathrm{~cm}$. They are irregular, and the columns are not cut off completely. There are microcracks cutting the columns into $10 \mathrm{~cm}$ diameter blocks. The growth of Type III columnar joints is poorly developed, and the rock can be treated as intact basalt.

The rock block shown in Figure 6 is compact cryptocrystal basalt. The rigid bearing plate method is used to estimate the strength, and a mean deformation modulus about $51.6 \mathrm{GPa}$ is obtained. It indicates that rock blocks have good stiffness and strength properties and the weak planes are the key factor affecting the mechanical properties of columnar basalt. The weak planes in columnar jointed basalt are mainly columnar joints, microfissures, and low-angle structural planes (including shearing band and fractures). Columnar joints and microfissures have typical distribution features like Voronoi diagram. They are closed without disturbance and open after perturbation. Low-angle shearing band is gently cutting the columns transversely. 
TABLE 3: The main factors in the classification of columnar jointed rock mass.

\begin{tabular}{cccccc}
\hline Factor & $\begin{array}{c}\text { Integrality index of } \\
\text { rock mass } K_{v}\end{array}$ & $\begin{array}{c}\text { Volumetric joint } \\
\text { number } J_{v}\end{array}$ & Rock block size $D(\%)$ & $\begin{array}{c}\text { Transverse hidden } \\
\text { joint development } \\
\text { degree } S(\mathrm{~m})\end{array}$ & $\begin{array}{c}\text { Intraformational faulted } \\
\text { zones development } \\
\text { degree } S L(\mathrm{~m})\end{array}$ \\
\hline Description & $\begin{array}{c}K_{V}=V_{p m}{ }^{2} / V_{p r}{ }^{2} \\
\text { velocities of rock } \\
\text { mass and intact rock. }\end{array}$ & $\begin{array}{c}\text { Sum of the linear } \\
\text { density of rock joint } \\
\text { in different } \\
\text { directions. }\end{array}$ & $\begin{array}{c}\text { The percentage of surface } \\
\text { area for the column with a } \\
\text { diameter over } 10 \mathrm{~cm} .\end{array}$ & $\begin{array}{c}\text { The mean distance } \\
\text { between two adjacent } \\
\text { transverse hidden } \\
\text { joints. }\end{array}$ & $\begin{array}{c}\text { The mean distance } \\
\text { between two adjacent } \\
\text { intraformational faulted } \\
\text { zones. }\end{array}$ \\
\hline
\end{tabular}

TABLE 4: Rock mass integrity classification.

\begin{tabular}{|c|c|c|c|c|c|}
\hline Rock mass integrity & Intact & Relatively intact & Poor intact & Relatively fractured & Fractured \\
\hline Integrality index of rock mass $K_{v}$ & $>0.75$ & $0.75 \sim 0.55$ & $0.55 \sim 0.35$ & $0.35 \sim 0.15$ & $<0.15$ \\
\hline Volumetric joint number $J_{v}\left(\mathrm{~m}^{3}\right)$ & $<3$ & $3 \sim 10$ & $10 \sim 20$ & $20 \sim 35$ & $>35$ \\
\hline Rock block size $D(\%)$ & $80 \sim 100$ & $50 \sim 80$ & $25 \sim 50$ & $15 \sim 25$ & $<15$ \\
\hline Transverse hidden joint development degree $S(\mathrm{~m})$ & $>20$ & $10 \sim 20$ & $5 \sim 10$ & $3 \sim 5$ & $<3$ \\
\hline Intraformational faulted zones development degree $S L(\mathrm{~m})$ & $>10$ & $3 \sim 10$ & $1.5 \sim 3$ & $1 \sim 1.5$ & $<1$ \\
\hline
\end{tabular}

TABLE 5: Weak plane tightness classification.

\begin{tabular}{|c|c|c|c|c|c|}
\hline Weak plane tightness & Tight & Relatively tight & Moderate tight & $\begin{array}{l}\text { Relatively } \\
\text { loose }\end{array}$ & Loose \\
\hline Weak plane opening $(\mathrm{mm})$ & $<0.5$ & $0.5 \sim 3$ & $3 \sim 5$ & $5 \sim 10$ & $>10$ \\
\hline $\begin{array}{l}\text { Columnar joints opening } \\
(\mathrm{mm})\end{array}$ & 0 & $<0.5$ & $0.5 \sim 1$ & $1 \sim 3$ & $>3$ \\
\hline Geological condition & Unweathering & $\begin{array}{c}\text { Slightly } \\
\text { weathering unweathering }\end{array}$ & $\begin{array}{c}\text { Weak weathering slightly } \\
\text { weathering }\end{array}$ & $\begin{array}{c}\text { Weak } \\
\text { weathering }\end{array}$ & Weathering \\
\hline
\end{tabular}

TABLE 6: Division standard of rock mass permeability.

\begin{tabular}{|c|c|c|c|c|c|}
\hline Permeability & Good & Relative good & Moderate good & Relatively bad & $\mathrm{Bad}$ \\
\hline Lugeon & $<1.5$ & $1.5 \sim 3.7$ & $3.7 \sim 8.1$ & $8.1 \sim 12$ & $>12$ \\
\hline
\end{tabular}

\section{Rock Classification for Columnar Jointed Basalt}

5.1. Columnar Basalt Classification. In columnar jointed rock masses, there exist both original and conformation structural planes, including faults, bedding fault zone, joints, and microfissures. For the distribution of weak planes without the consideration of the compact degree of structural planes, the linear density of rock joints is as high as 15 strips per meter. Therefore, the RQD of columnar basalt is low and would be categorized as weak rock mass. However, the mechanical properties, such as strength and seismic velocity $\left(V_{p}\right)$, are quite high so that columnar jointed basalt can be classified as good rock mass in some rock mass classification systems. Due to the special features of columnar jointed basalt and the inconsistency between geometric discontinuity and mechanical properties, conventional classification schemes may be not suitable; special analysis is required in the classification of columnar jointed rock mass.

In the development of a classification scheme of columnar jointed basalt, the following factors are taken into account. Based on the application environment, the main factors controlling the structure and quality of columnar rock mass are estimated first. In most rock classification schemes, the factor of water is absent. However, columnar jointed rock mass in Baihetan distributes at the dam foundation and will suffer from super high pore water pressure with a height over $200 \mathrm{~m}$. Therefore, water permeability is inevitable in classifying rock mass with underground water. Furthermore, the degree of compact of joints, geometric integrity, structural type, and weathering are also taken into consideration. Adopting the strength parameter from RMR and employing the description and analysis of geometric and geological characteristics, a rock classification scheme for columnar jointed rock is developed in the following.

\subsection{The Main Factors and Indexes in Classification System}

5.2.1. The Rock Mass Strength. The rock mass strength is the most important parameter in rock classification and almost every scheme takes it as the first parameter. In RMR scheme, 
TABLE 7: Columnar jointed rock classification scheme.

\begin{tabular}{|c|c|c|c|c|c|c|}
\hline Level & Sublevel & $\begin{array}{l}\text { UCS } \\
(\mathrm{MPa})\end{array}$ & Rock mass integrity & $\begin{array}{l}\text { Weak plane } \\
\text { tightness }\end{array}$ & $\begin{array}{l}\text { Permeability } \\
\text { (Lu) }\end{array}$ & Basic features \\
\hline I & & $>200$ & Intact & Tight & $<0.9$ & $\begin{array}{l}\text { Rock mass is hard and intact with blocky structure. It is } \\
\text { fresh without unloading effect and has extremely low } \\
\text { permeability. Columnar joint is not developed and the } \\
\text { rock mass in this level can be used as directly without any } \\
\text { treatment. }\end{array}$ \\
\hline II & & $100 \sim 200$ & Relatively intact & Tight & $0.9 \sim 1.5$ & $\begin{array}{c}\text { Rock mass is hard and relatively intact without or slightly } \\
\text { weathered. Column is short and wide with blocky } \\
\text { structure. The permeability is slight and rock mass can } \\
\text { be used with local treatment. }\end{array}$ \\
\hline \multirow{2}{*}{ III } & $\mathrm{III}_{1}$ & $50 \sim 100$ & $\begin{array}{c}\text { Relatively } \\
\text { intact } \sim \text { poor intact }\end{array}$ & $\begin{array}{l}\text { Relatively } \\
\text { tight } \sim \text { tight }\end{array}$ & $1.5 \sim 2.6$ & $\begin{array}{c}\text { Rock mass in this level is relatively intact and slightly } \\
\text { weathered. Columnar joint develops and make the } \\
\text { columns have columnar mosaic texture. The weak plane } \\
\text { is tight and this level rock can be used under simple } \\
\text { engineering treatment. }\end{array}$ \\
\hline & $\mathrm{III}_{2}$ & $25 \sim 50$ & Poor intact & $\begin{array}{l}\text { Moderate } \\
\text { tight } \sim \text { relatively } \\
\text { tight }\end{array}$ & $2.6 \sim 3.7$ & $\begin{array}{l}\text { Rock mass is poor intact and weak weathered. Columnar } \\
\text { joints develop and make the columns have columnar } \\
\text { mosaic texture. The weak plane is relatively tight and the } \\
\text { permeability is poor. Rock mass can be used under } \\
\text { certain treatment. }\end{array}$ \\
\hline \multirow{2}{*}{ IV } & $\mathrm{IV}_{1}$ & $10 \sim 25$ & $\begin{array}{l}\text { Relatively } \\
\text { fractured poor } \\
\quad \text { intact }\end{array}$ & $\begin{array}{l}\text { Moderately } \\
\text { tight } \sim \text { relatively } \\
\text { loose }\end{array}$ & $3.7 \sim 8.1$ & $\begin{array}{l}\text { Rock mass is relatively fractured with weak unloading } \\
\text { effect. Weak plane is moderately tight and develops in } \\
\text { columns, making the rock in block-fracture structure. } \\
\text { This kind of rock has relatively strong permeability and } \\
\text { cannot be used as dam foundation directly. }\end{array}$ \\
\hline & $\mathrm{IV}_{2}$ & $3 \sim 10$ & $\begin{array}{l}\text { Fractured relatively } \\
\text { fractured }\end{array}$ & Relatively loose & $8.1 \sim 12$ & $\begin{array}{l}\text { Rock mass is relatively fractured with intensive } \\
\text { unloading effect. Weak plane develops adequately and } \\
\text { the rock has cataclastic structure with strong water } \\
\text { permeability. Rock mass in this level cannot be used and } \\
\text { needs to be removed. }\end{array}$ \\
\hline V & & $<3$ & Fractured & $\begin{array}{l}\text { Relatively } \\
\text { loose loose }\end{array}$ & $>12$ & $\begin{array}{l}\text { There are large-scale intraformational faulted zones and } \\
\text { open weak planes. The rock mass is extremely fractured } \\
\text { with fragmental block structure. }\end{array}$ \\
\hline
\end{tabular}

uniaxial compressive strength (UCS) of intact rock is employed as the representative strength parameter. Considering RMR has been widely applied in a large number of engineering projects, the classification of Baihetan columnar joints uses the same parameter as RMR classification standard (Table 2).

5.2.2. Rock Mass Integrity. Rock integrity is a key factor affecting the quality of rock mass. For hard rock blocks, the integrity is determined by the development of joints. In the analysis of the degree of integrity of columnar basalt, column sizes and hidden joints are also considered. For a comprehensive analysis of columnar jointed basalt, five quantitative parameters are employed (Table 3 ).

Columnar jointed rock masses have complex structures, and a single factor cannot describe the integrity of rock masses accurately. In this rock classification system, a quantitative categorization of rock mass integrity is listed in Table 4.

5.2.3. Weak Plane Tightness. Existing rock classification systems usually neglect the tightness of weak planes. However, the tightness of columnar joints is extremely important in the rock characteristics. For columnar jointed basalt, the tightness of rock joint is determined based on open distance, filling material, and degree of weathering. A detail description of weak plane tightness is presented in Table 5 .

5.2.4. Rock Mass Permeability. Underground water condition is one of the five important parameters in RMR rock classification system. Considering the columnar jointed rock mass is in the foundation of the dam with a height of $289 \mathrm{~m}$, the underground water problem is serious and the columnar jointed rock mass is saturated [53]. Permeability obtained from site packer permeability test is used for the classification of columnar jointed rock mass (Table 6).

\subsection{Columnar Jointed Rock Classification System and Application}

5.3.1. Classification Scheme. The proposed columnar jointed rock mass classification system is based on three main factors. This scheme categorizes rock mass into five levels and seven sublevels. Related quantitative indices are listed in 


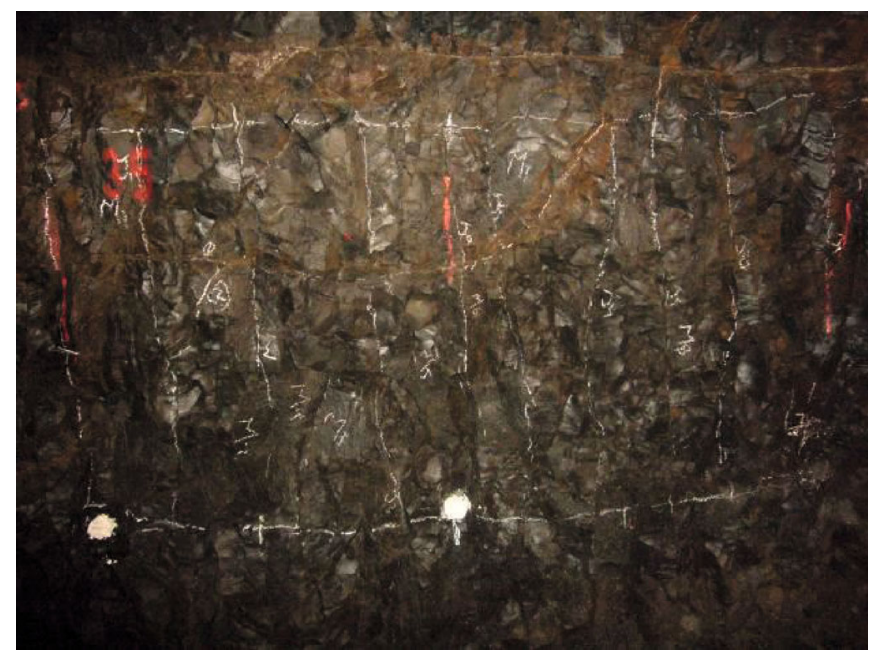

(a)

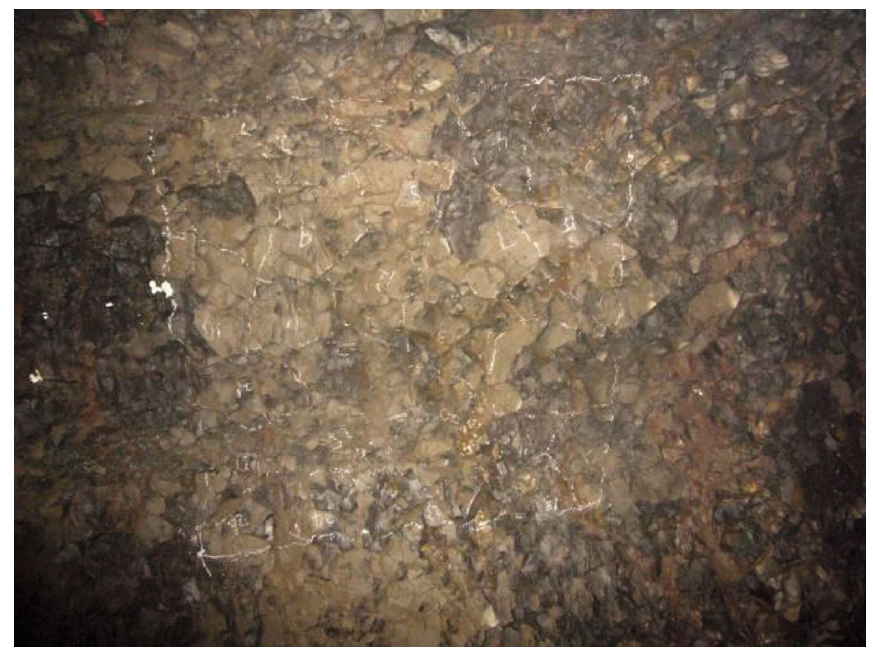

(c)

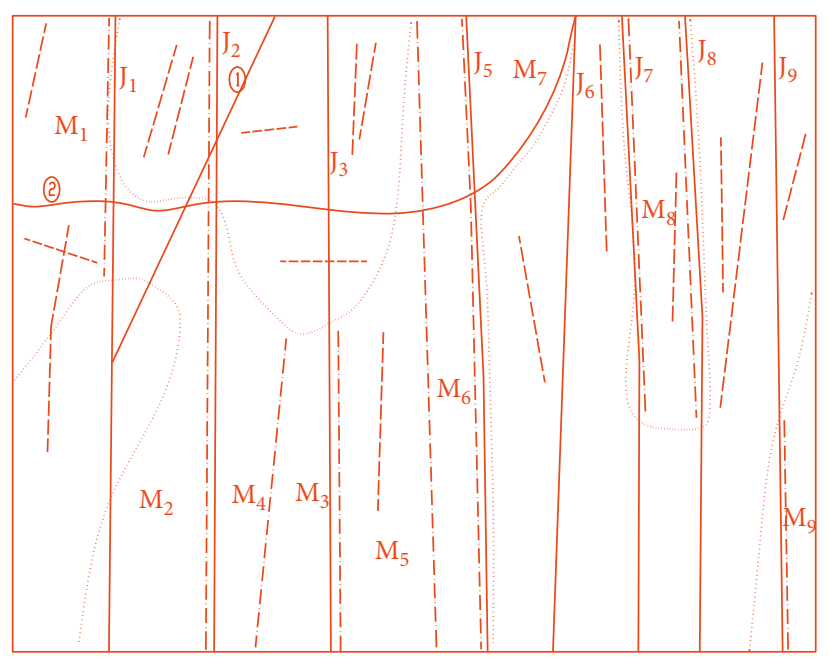

(b)

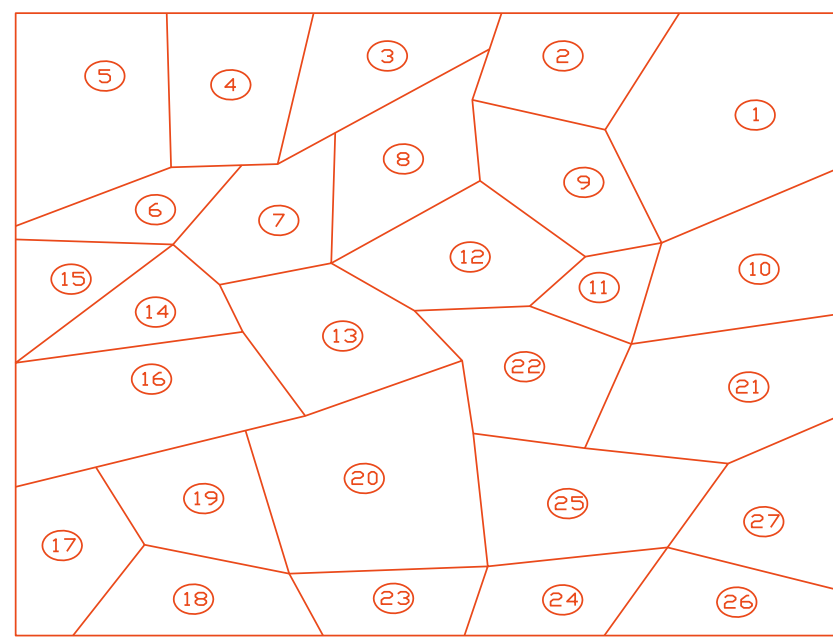

(d)

FIGURE 7: Illustration of microcrack in columnar jointed basalt of PD37: (a) the original photo of adit wall, (b) geologic sketch map of adit wall, (c) the original photo of adit top, and (d) geologic sketch map of adit top.

Table 7. Rock mass in levels I to III can be considered in the construction of dam foundation.

5.3.2. Application. After the introduction of the proposed classification system, a simple example for rock mass in $P_{2}$ $\beta_{3}{ }^{3}$ is used to demonstrate the application of this new classification scheme. Take the information in PD37 (shown in Figure 3) as example; this kind of rock mass is distributed at a distance about 20 to $40 \mathrm{~m}$ to the entrance. The slightly weathered columnar basalt is shown in Figure 7 and it indicates that this kind of rock has relatively obvious columnar outline.

The columns are irregular and twisty with a length of 2 to $3 \mathrm{~m}$ and a diameter of 13 to $25 \mathrm{~cm}$. The dipping angle is about 70 to $85^{\circ}$, and the shape of section is mainly pentagon or tetragon. Besides the columnar joints, there have developed a certain number of microfissures in the columns, and the per- centage of microfissures with diameters over $10 \mathrm{~cm}$ is about $27 \%$. Microfissures are mainly parallel to the columnar joints with trace lengths from 0.3 to $2 \mathrm{~m}$, and the density is shown in Figure 8(a). The faces of microfissures are tortuous and closed. The mean $J_{v}$ value is about 8.8 per $\mathrm{m}^{3}$. From Figure $8(\mathrm{~b})$, the average seismic wave velocity is 3800 which leads to an integrity factor which is about 0.48 meaning a poor contact condition. Besides, the mean distance between two adjacent transverse hidden joints is less than $8.5 \mathrm{~cm}$. The mean distance between two adjacent intraformational faulted zones is about $5.5 \mathrm{~m}$ and can be categorized as "slightly developed."

The opening widths of columnar joints are about 0.5 to $1.0 \mathrm{~mm}$ and those of microfissures are less than $0.5 \mathrm{~mm}$. The weak planes are "relatively tight" based on the categorization scheme. Water pressure test shows that the permeability is about 2.6 to $6.2 \mathrm{Lu}$. Referring to the classification criteria, the rock integrity is "poor intact," and the weak 


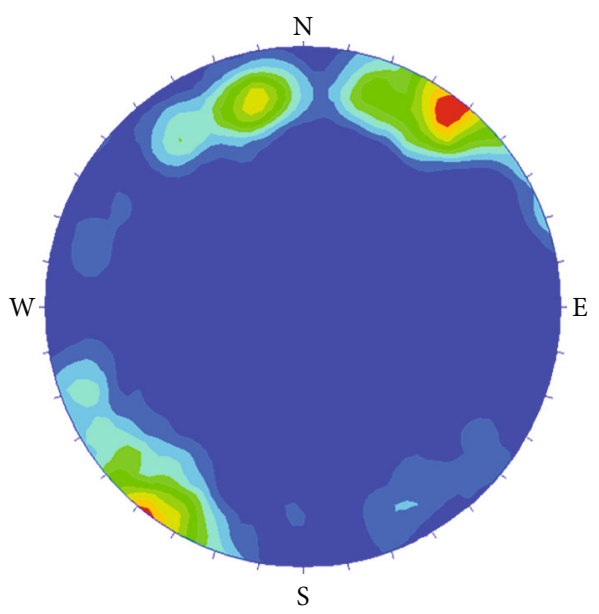

(a)

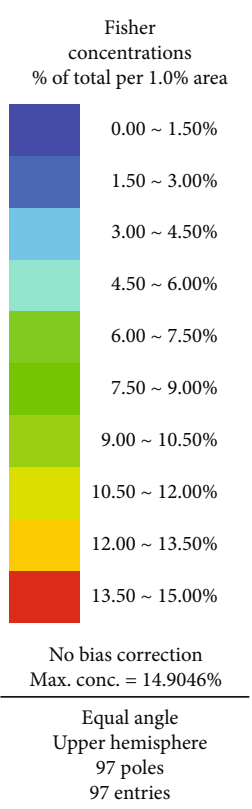

97 entries

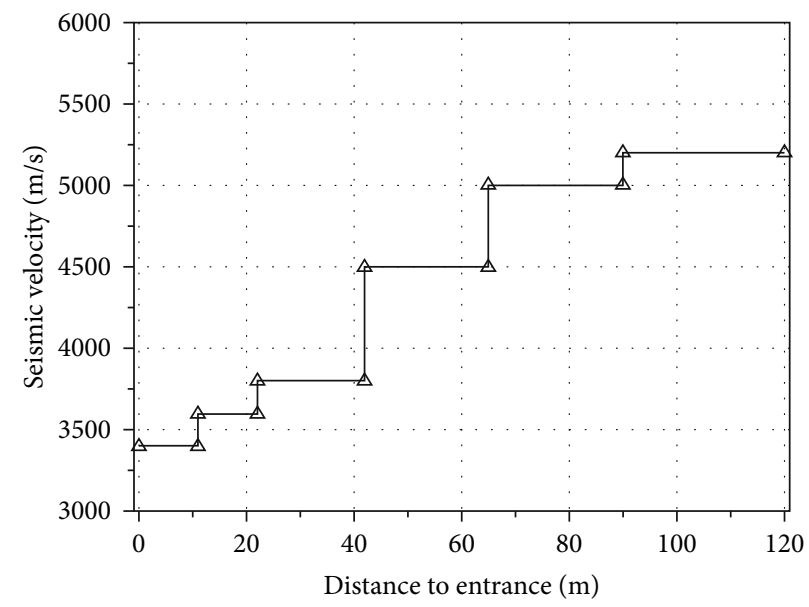

FIGURE 8: Microfissures and seismic velocity in adit PD37: (a) isodensity map and (b) seismic wave velocity.

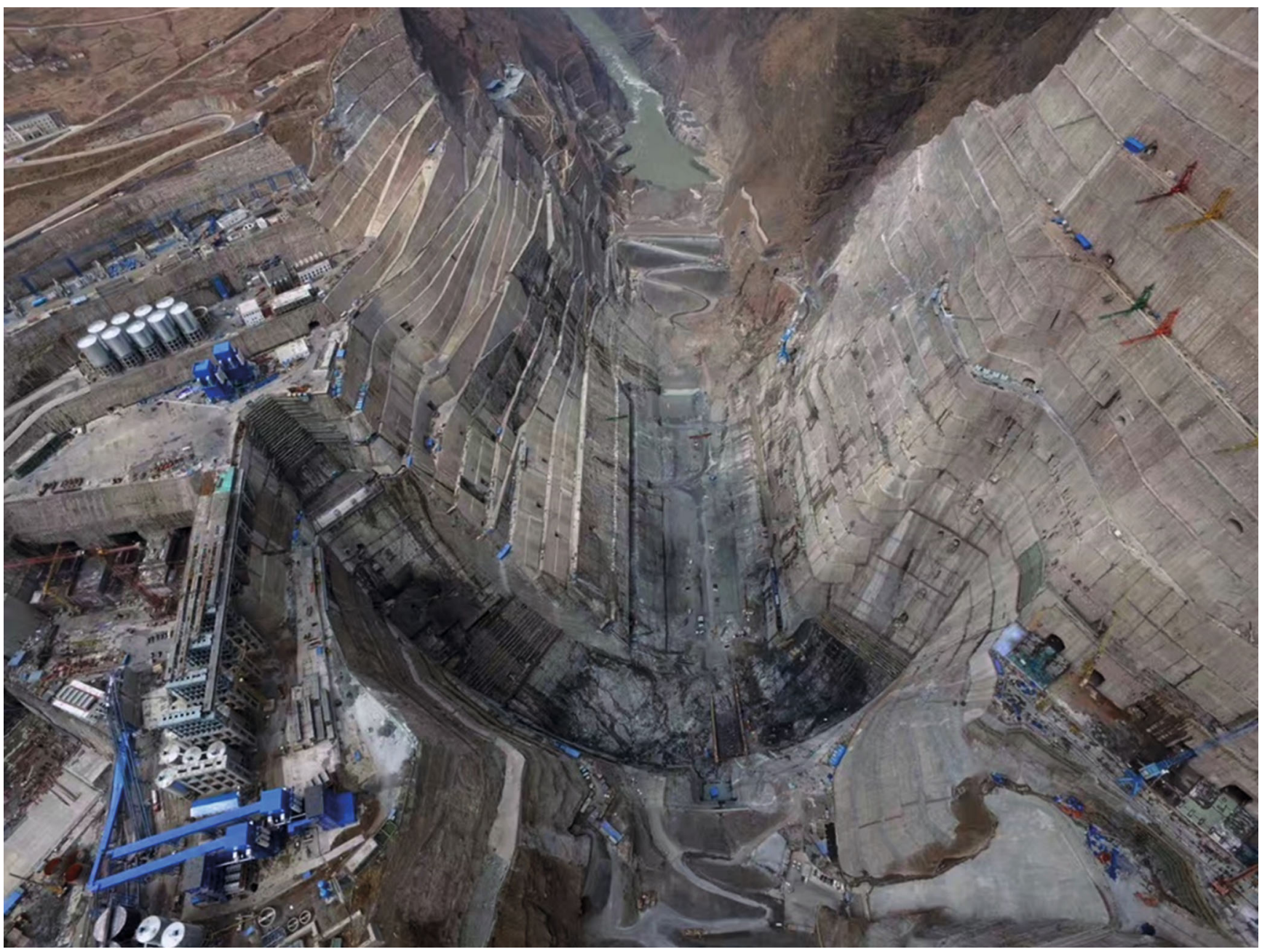

FIgURE 9: The final excavation of the Baihetan dam foundation. 
planes are "relatively tight." Hence, the level of columnar jointed basalt in this part of the foundation is $\mathrm{III}_{2}$. Rock mass cannot be employed as dam foundation directly, but can be used under effective reinforcement treatment.

Using the classification for columnar jointed basalt in Baihetan, the excavation scheme is designed for rock mass with different levels. The whole excavation process is very successful, and the final image of the dam foundation is shown in Figure 9. Now, the construction of dam is nearly finished. The result indicates that the rock classification is feasible for the related engineering with columnar jointed rock.

\section{Conclusion}

Baihetan hydropower station is the first arch dam built on the foundation with columnar jointed rock mass. Columnar jointed rock mass is special in that it is discrete in geometry but is still of high quality like intact blocks. For columnar jointed basalt, the strength and deformability features are mainly governed by rock-to-rock contacts. The tightness of weak planes plays an important role in the rock classification. Since the rock mass is located at the dam foundation, the effect of permeability is important. Existing rock classification schemes cannot give a comprehensive estimation due to the absence of these critical factors.

A rock mass classification scheme for columnar jointed basalt is proposed based on rock integrity, weak plane tightness, and permeability. With the help of a number of measures, such as seismic wave velocity, and geology descriptions, such as microfissures, this work tries to present a more suitable scheme. As an attempt for columnar jointed basalt, this work is also valuable as reference for similar rock masses.

\section{Data Availability}

Data are available on request.

\section{Conflicts of Interest}

The authors declare that they have no conflicts of interest.

\section{Acknowledgments}

This research is supported by the National Key R\&D Program of China (No. 2018YFC0407004), the Fundamental Research Funds for the Central Universities (B200201059), and the Natural Science Foundation of China (Grant Nos. 51709089, 51939004, 12062026, and 11772116).

\section{References}

[1] L. Goehring, On the Scaling and Ordering of Columnar Joints, University of Toronto, 2008.

[2] X.-W. Xu, "Columnar jointing in basalt, Shandong Province, China," Journal of Structural Geology, vol. 32, no. 10, p. 1403, 2010.

[3] R. Bulkeley, "IV. Part of a letter from Sir R. B. S. R. S. to Dr. Lister, concerning the Giants Causway in the County of Atrim iu Ireland," Philosophical Transactions of the Royal Society of London, vol. 17, no. 199, pp. 708-710, 1693.

[4] P. Budkewitsch and P.-Y. Robin, "Modelling the evolution of columnar joints," Journal of Volcanology and Geothermal Research, vol. 59, no. 3, pp. 219-239, 1994.

[5] J. M. DeGraff, P. E. Long, and A. Aydin, "Use of joint-growth directions and rock textures to infer thermal regimes during solidification of basaltic lava flows," Journal of Volcanology and Geothermal Research, vol. 38, no. 3-4, pp. 309-324, 1989.

[6] M. P. Ryan and C. G. Sammis, "Cyclic fracture mechanisms in cooling basalt," Geological Society of America Bulletin, vol. 89, no. 9, pp. 1295-1308, 1978.

[7] M. P. Ryan and C. G. Sammis, "The glass transition in basalt," Journal of Geophysical Research: Solid Earth, vol. 86, no. B10, pp. 9519-9535, 1981.

[8] X. Wang, C. Liu, S. Chen, L. Chen, K. Li, and N. Liu, "Impact of coal sector's de-capacity policy on coal price," Applied Energy, vol. 265, article 114802, 2020.

[9] Q. Meng, H. Wang, M. Cai, W. Xu, X. Zhuang, and T. Rabczuk, "Three-dimensional mesoscale computational modeling of soil-rock mixtures with concave particles," Engineering Geology, vol. 277, article 105802, 2020.

[10] Q. Meng, H. Wang, M. He, J. Gu, J. Qi, and L. Yang, “Displacement prediction of water-induced landslides using a recurrent deep learning model," European Journal of Environmental and Civil Engineering, pp. 1-15, 2020.

[11] Q. Jiang, X. T. Feng, Y. H. Hatzor, X. J. Hao, and S. J. Li, "Mechanical anisotropy of columnar jointed basalts: an example from the Baihetan hydropower station, China," Engineering Geology, vol. 175, pp. 35-45, 2014.

[12] Y. J. Cao, W. Q. Shen, J. F. Shao, and W. Wang, "A novel FFTbased phase field model for damage and cracking behavior of heterogeneous materials," International Journal of Plasticity, vol. 133, article 102786, 2020.

[13] Y. J. Cao, W. Q. Shen, N. Burlion, and J. F. Shao, "Effects of inclusions and pores on plastic and viscoplastic deformation of rock-like materials," International Journal of Plasticity, vol. 108, pp. 107-124, 2018.

[14] Y. J. Cao, W. Q. Shen, J. F. Shao, and N. Burlion, "Influences of micro-pores and meso-pores on elastic and plastic properties of porous materials," European Journal of Mechanics A/Solids, vol. 72, pp. 407-423, 2018.

[15] J. Chen, J. Zhao, S. Zhang, Y. Zhang, F. Yang, and M. Li, “An experimental and analytical research on the evolution of mining cracks in deep floor rock mass," Pure and Applied Geophysics, vol. 177, no. 11, pp. 5325-5348, 2020.

[16] C. Zhu, M. He, M. Karakus, X. Cui, and Z. Tao, "Investigating toppling failure mechanism of anti-dip layered slope due to excavation by physical modelling," Rock Mechanics and Rock Engineering, vol. 53, no. 11, pp. 5029-5050, 2020.

[17] Q.-X. Meng, H. L. Wang, W. Y. Xu, and M. Cai, “A numerical homogenization study of the elastic property of a soil-rock mixture using random mesostructure generation," Computers and Geotechnics, vol. 98, pp. 48-57, 2018.

[18] L. Yan, W. Xu, R. Wang, and Q. Meng, "Numerical simulation of the anisotropic properties of a columnar jointed rock mass under triaxial compression," Engineering Computations, vol. 35, no. 4, pp. 1788-1804, 2018.

[19] J. Wang, Y. Zhang, Z. Qin, S. Song, and P. Lin, “Analysis method of water inrush for tunnels with damaged waterresisting rock mass based on finite element method-smooth 
particle hydrodynamics coupling," Computers and Geotechnics, vol. 126, p. 103725, 2020.

[20] B. Chen, S. Zhang, Y. Li, Z. Li, and H. Zhou, "Physical simulation study of crack propagation and instability information discrimination of rock-like materials with faults," Arabian Journal of Geosciences, vol. 13, no. 18, p. 966, 2020.

[21] D. Liu, Z. Gu, R. Liang et al., "Impacts of pore-throat system on fractal characterization of tight sandstones," Geofluids, vol. 2020, Article ID 4941501, 17 pages, 2020.

[22] Y. Zhou, S.-c. Qi, L. Wang, M.-1. Chen, C. Xie, and J.-w. Zhou, "Instability analysis of a quaternary deposition slope after two sudden events of river water fluctuations," European Journal of Environmental and Civil Engineering, In press.

[23] Y.-x. Hu, Z.-y. Yu, and J.-w. Zhou, "Numerical simulation of landslide-generated waves during the 11 October 2018 Baige landslide at the Jinsha River," Landslides, vol. 17, no. 10, pp. 2317-2328, 2020.

[24] J.-w. Zhou, H.-b. Li, G.-d. Lu, Y. Zhou, J.-y. Zhang, and G. Fan, "Initiation mechanism and quantitative mass movement analysis of the 2019 Shuicheng catastrophic landslide," Quarterly Journal of Engineering Geology and Hydrogeology, In press.

[25] J. Zhang, W. Q. Shen, Q. Z. Zhu, and J. F. Shao, "A homogenized macroscopic criterion for shakedown analysis of ductile porous media with kinematical hardening matrix," European Journal of Mechanics - A/Solids, vol. 82, p. 104015, 2020.

[26] J. Zhang, A. Oueslati, W. Q. Shen et al., "Shakedown analysis of a hollow sphere by interior-point method with non-linear optimization," International Journal of Mechanical Sciences, vol. 175, article 105515, 2020.

[27] W. Wang, L.-q. Li, W.-y. Xu, Q.-x. Meng, and J. Lü, “Creep failure mode and criterion of Xiangjiaba sandstone," Journal of Central South University, vol. 19, no. 12, pp. 3572-3581, 2012.

[28] W. Ritter, Die Statik der Tunnelgewölbe, Springer, Berlin, Germany, 1879.

[29] K. Terzaghi, "Rock defects and loads on tunnel supports," in Rock Tunneling with Steel Support: With an Introduction to Tunnel Geology, R. Proctor, T. White, and K. Terzaghi, Eds., pp. 17-99, Commercial Shearing and Staming Company, Youngstown, OH, USA, 1946.

[30] H. Lauffer, "Gebirgsklassifizierung fur den stol lenbau," Geologie und Bauwesen, vol. 24, no. 1, pp. 46-51, 1958.

[31] D. U. Deere, "Technical description of rock cores for engineering purposes," Rock Mechanics and Engineering Geology, vol. 1, no. 1, pp. 17-22, 1963.

[32] G. Wickham, H. Tiedemann, and E. H. Skinner, "Support determinations based on geologic predictions," in Proceedings of the 1st North American Rapid Excavation Tunneling Conference, pp. 43-64, New York, NY, USA, 1972.

[33] N. Barton, R. Lien, and J. Lunde, "Engineering classification of rock masses for the design of tunnel support," Rock Mechanics, vol. 6, no. 4, pp. 189-236, 1974.

[34] Z. T. Bieniawski, "Engineering classification of jointed rock masses," Transactions of the South African Institution of Civil Engineers, vol. 15, pp. 335-344, 1973.

[35] A. Palmstrom, RM -A Rock Mass Characterization System for Rock Engineering Purposes, Oslo University, Oslo, Norway, 1995.

[36] L. V. Rabcewicz, "The new Austrian tunnelling method," Water Power, vol. 16, pp. 453-456, 1964.
[37] D. Laubscher, "A geomechanics classification system for the rating of rock mass in mine design," Journal of the Southern African Institute of Mining and Metallurgy, vol. 90, pp. 257273, 1977.

[38] M. Selby, "A rock mass strength classification for geomorphic purposes: with tests from Antarctica and New Zealand," Zeitschrift für Geomorphologie, vol. 24, pp. 31-51, 1980.

[39] M. Romana, "New adjustment ratings for application of Bieniawski classification to slopes," in Proceedings of the International Symposium on the Role of Rock Mechanics in Excavations for Mining and Civil Works, pp. 49-53, Zacatecas, Mexico, 1985.

[40] A. M. Robertson, "Estimating weak rock strength," in SME Annual Meeting, pp. 1-5, Society of Mining Engineers, Phoenix, AZ, USA, 1988.

[41] Z. Chen, Recent Developments in Slope Stability Analysis, in: 8th ISRM Congress, International Society for Rock Mechanics, 1995.

[42] E. Hoek, P. K. Kaiser, and W. F. Bawden, Support of underground excavations in hard rock, CRC Press, 2000.

[43] E. Unal, "Modified rock mass classification: M-RMR system," in Milestones in Rock Engineering, the Bieniawski Jubilee Collection, pp. 203-223, Balkema, Rotterdam, Netherlands, 1996.

[44] China Ministry of Water, Standard for Engineering Classification of Rock Mass, China Planning Press, Beijing, China, 1995.

[45] D. T. Nicholson and S. Hencher, "Assessing the potential for deterioration of engineered rockslopes," in Proceedings of the IAEG symposium, pp. 911-917, Athens, Greece, 1997.

[46] R. Hack, D. Price, and N. Rengers, "A new approach to rock slope stability-a probability classification (SSPC)," Bulletin of Engineering Geology and the Environment, vol. 62, no. 2, pp. 167-184, 2003.

[47] A. Singh and M. Connolly, "VRFSR: an empirical method for determining volcanic rock excavation safety on construction sites," Journal of the Institution of Engineers. India. Civil Engineering Division, vol. 84, pp. 176-191, 2003.

[48] A. Singh, "FRHI-: a system to evaluate and mitigate rockfall hazard in stable rock excavations," Journal of the Institution of Engineers. India. Civil Engineering Division, vol. 85, pp. 62-75, 2004.

[49] ISRM, "Basic geotechnical description of rock masses," International Journal of Rock Mechanics Mining Sciences and Geomechanics Abstracts, vol. 18, pp. 85-110, 1981.

[50] J. A. Franklin, "Safety and economy in tunneling," in Proceedings of the 10th Canadian Rock Mechanics Symposium, pp. 2753, Ontario, 1975.

[51] N. Brook and P. Dharmaratne, Simplified Rock Mass Rating System for Mine Tunnel Support, Institution of Mining and Metallurgy Transactions, 1985.

[52] Q. Meng, L. Yan, Y. Chen, and Q. Zhang, "Generation of numerical models of anisotropic columnar jointed rock mass using modified centroidal Voronoi diagrams," Symmetry, vol. 10, no. 11, p. $618,2018$.

[53] J. Dou, M. Zhou, Z. Wang et al., "Case study: in situ experimental investigation on overburden consolidation grouting for columnar jointed basalt dam foundation," Geofluids, vol. 2020, Article ID 1865326, 18 pages, 2020. 